\title{
Crisis, Stimulus Package and Migration in China
}

\author{
dr.Maria Csanádi (contact person) \\ Center for Economic and Regional Studies, Institute of Economics \\ Budapest, Budaörsi út 45 \\ Hungary, H-1112 \\ tel: +36308164260 \\ csanadi.maria@krtk.mta.hu
}

Nie Zihan

Beijing Normal University

School of Economics and Business Administration ${ }^{1}$

Room 3112. Leeuwenborch, Hollandseweg 1, 6706KN, Wageningen, the Netherlands

tel: $+310317-482978$

zihan.nie@wur.nl

dr. Li Shi

Beijing Normal University

School of Economics and Business Administration

19 Xin Jie Kou Wai Da Jie, Beijing, China,

tel: $+86-10-58802940$

lishi@bnu.edu.cn

word count (including tables and figures) 11,890

\section{Acknowledgement}

This research was financed by the Hungarian National Research Fund. Special thanks to

Ferenc Gyuris ELTE TTK Regional Science Department in Hungary to compose the maps in

\footnotetext{
${ }^{1}$ Currently at Development Economics Group, Wageningen University, the Netherlands
} 
the paper.

\title{
Crisis, Stimulus Package and Migration in China
}

\begin{abstract}
:
Authors of this paper trace the influence of the crisis and the stimulus package in China on its rural to urban migration between 2008 and 2011. The package had clear ownership, scale, sectoral and regional priorities deemed to decrease the country's export exposure. Since migrant flow was export-sensitive, we hypothesized that opposite priorities will have a sound restructuring effect on thus far migrant routes. Migrants have sensitively reacted to stimulus priorities revealed in the reorientation of migrant routes from the coastal towards the central and western regions, from interprovincial towards intra-provincial migration, and from manufacturing industry towards the construction sector. Thus, on the longer term, priorities of the stimulus package have reinforced the short-term regional and sectoral export-sensitive impact of the crisis.
\end{abstract}

Key words: migration, employment, stimulus package, crisis, spatial disparities

JEL code: E24, R23, P23, F5, R2 J08

\section{Introduction: economic context and dynamics}

The global economic crisis in 2008 had a sweeping effect on the Chinese economy. Major economic indicators on Table 1 in 2009 reflect the dramatic set-back both in the yearly dynamics of the GDP, export, Gross Industrial Output Value and in FDI.

Table 1. Factors influenced by the crisis and the stimulus package (year-on-year percent) 


\begin{tabular}{|l|c|c|c|c|c|}
\hline GDP & 14.2 & 9.6 & 9.2 & 10.4 & 9.3 \\
\hline $\begin{array}{l}\text { Gross Industrial output } \\
\text { value }\end{array}$ & 28.0 & 25.2 & 8.1 & 31.3 & 20.3 \\
\hline Export & 26.0 & 17.2 & -16.0 & 31.3 & 20.3 \\
\hline FDI & 18.6 & 23.6 & -2.6 & 17.4 & 9.7 \\
\hline
\end{tabular}

Source: http://www.stats.gov.cn/english/statisticaldata/yearlydata/

Meanwhile, investments and loans followed the opposite tendency: investments increased radically in 2009, while loans skyrocketed (Table 2). Behind this investment boom, a change in prior sectoral and regional focus may be perceived: investment growth in manufacturing slowed down while compared to 2008 , the pace of investments in construction radically increased in 2009 and it doubled by 2010 .

Table 2. Dynamics of national and sectoral level investments (year-on-year percent)

\begin{tabular}{|l|c|c|c|c|c|}
\hline & 2007 & 2008 & 2009 & 2010 & 2011 \\
\hline Investments & 24.8 & 25.9 & 30.0 & 23.8 & 12.0 \\
\hline Loans & 39.7 & 17.0 & 99.3 & 0.8 & $\mathbf{- 8 . 5}$ \\
\hline $\begin{array}{l}\text { Investment in } \\
\text { manufacturing }\end{array}$ & 30.6 & 27.4 & 24.5 & 25.5 & 15.9 \\
\hline $\begin{array}{l}\text { Investment in } \\
\text { construction }\end{array}$ & 15.7 & 19.5 & 28.1 & 40.6 & 19.8 \\
\hline
\end{tabular}

Source: http://www.stats.gov.cn/english/statisticaldata/yearlydata/

Not only sectoral, but also regional clusters of investment dynamics have changed. Investment growth was the fastest in the central and western regions as opposed to the coastal provinces where export was concentrated. Also a regional sectoral characteristic has evolved by 2009-2010 since investments in construction grew at a higher pace in the central and western regions compared to that of the coastal provinces (see maps in Csanádi, Nie, Li, 2013) The radical growth of investments and loans in 2009 and the subsequently increasing rate of investment in construction in 2009 and 2010 overwhelmingly in the central and western regions was the result of the 4 trillion $\mathrm{CNY}$ (612.06 billion USD) stimulus package and that of its sectoral and regional priorities introduced by the central government in late 2008. The purpose of the package was to compensate GDP decline, decrease export dependency and 
stimulate economic growth. Therefore, investments were oriented towards sectors serving domestic consumption rather than exports; focused on the development of infrastructure instead of the overwhelmingly export-oriented manufacturing sector; prioritized large scale as opposed to small and middle sized enterprises that dominate export industries; state owned rather than private enterprises were prefered in the distribution of resources; and oriented to central and western regions instead of the exporting and economically developped coastal provinces (Csanádi, 2013; Csanádi, Nie, Li, 2013).

China's crisis management between 2008 and 2011 proved to be successful. The national and local level responses to the global crisis met the original goals of compensating economic decline and reducing export reliance. Different level governments and banks became promptly active, investments accelerated, economic indicators quickly improved, and unemployment rate soon dropped to the pre-crisis level. Infrastructural investments at prioritized central and western regions skyrocketed. Investments soon had multiplicative effect, since input demands in priority regions, in infrastructure and construction sectors and large state-owned enterprises activated the small and medium enterprises and the private sector in manufacturing, overwhelmingly at central and western regions but also at coastal provinces (Csanádi, 2012; Csanádi, 2013; Csanádi, Nie, Li, 2013).

Both the crisis and the implementation of this priority investment concept strongly influenced the then 140 million migrant workers' fate regarding their regional destination and place of origin, their earning and living conditions, migration distances, migrant labor market etc. During this period, extensive literature was born on the problems of migration and economic growth (Knight et. al. 2013), income disparities among urban and rural regions (Sicular at. al, 2005; Yu, 2011, Li Shi, 2013), migrant labor market constraints (hukou system) and migrant living conditions at urban locations (Chan, 2013). Also income disparities among migrants and urban workers (Duggan, 2013), attitude differences among first and second generation of 
migrants (Chiang and al.. 2013; Hu, 2012) were profoundly studied. Besides traditional topics, the crisis and development raised several new issues: the puzzle of migrant unemployment and simultaneous labor shortage (Knight at al, 2010; Xu. 2010), crisis and migration (Wong, S.. 2008; Cai and Chan. 2010; Hsu et al. 2010; Kong et al.. 2010; Meng et al. 2010) and the reasons of mass grievances (Cai, Y. 2010).

We would like to contribute to the complexity of the above issues with a new dimension: the sensitivity of migrant flow to the crisis and the reflection of this sensitivity in the regional, sectoral priorities of the stimulus package. ${ }^{2}$ We wanted to find out to what extent cumulated dynamics of these two processes have changed or left unharmed the so far structural characteristics of migrant flow. The originality of this approach compared to other migration studies is that instead of submerging in the analysis of one specific field, we make an effort to detect direct and indirect causal relationships among several fields influencing migration: the consequences of economic dynamics, crisis, state intervention, and resource distribution priorities on migration.

The rest of the paper was organized as follows: we form our hypothesis in Chapter II and introduce the data and methodology in Chaper III. Based on those, we identify the consequences of the crisis on migrant flow in Chapter IV and the impact of major factors of the stimulus package on the restructuring of migrant flow, V and VI. These chapters are followed by the conclusion in chapter VII.

\section{Hypothesis: Migrants' high sensitivity to economic dynamics}

On national level, migrants' sensitivity to the crisis was dramatic. About 16 percent (23 million) of migrants became suddenly unemployed compared to about the four percent of

\footnotetext{
${ }^{2}$ Other priorities of the stimulus package as ownership and size of enterprises where migrants work unfortunately cannot be analyzed from the available migrant data.
} 
urban workforce (Chan, 2010, p. 251). The reasons of the strong interdependency between migration and crisis was evident: 71 percent of the migrants were working in the crisis-hit eastern provinces (NBS report, 2008) where the production of exported manufacturing goods was concentrated, overwhelmingly in small- and medium sized foreign and domestic private enterprises (Chan, 2013, p. 13). The crisis intensified the high mobility of migrant workers. The constant sensitivity of migrants to external dynamics emerges from their comparatively unfavorable economic, social and economic policy context that defines migrant labor market conditions. In this context, migrants are weakly rooted: they are officially denied of urban household registration (hukou) that would allow urban settlement and local social services; a low ratio of migrants have labor contract and insurances, lower wages, work more days and for longer hours, they are scarcely unionized, have lower capacity to promote individual and collective interest. Therefore, migrants are more exposed to both employers and economic dynamics than urban residents. On the other hand, employers who use unrooted migrant labor are less constrained by legal commitments and social pressure to improve working and living conditions. Thus, they can easily manoeuver migrant exposure according to their actual business needs. Migrants' exposure and enterpreneur's capacity together will result in high mobility, be it either forced, or chosen as protest or as a way of interest promotion. Higher mobility of migrants and their sensitivity to crisis and stimulus package is supported by the distribution and change in the employment distribution of urban units, urban private enterprises and self-employed individuals and migrant labor in 2008 and 2009 in Table 3. According to Table 3 distribution of the work force in 2008 was uneven in all categories of labor reflecting the sensitivity to the concentration of the industry and export to the eastern provinces. However, already in 2008 we can see the higher sensitivity of migrants with well over two-thirds located in the export oriented eastern region compared to the half of urban units and 58 percent of urban private and self-employed labor. Sensitivity and mobility of 
migrants is revealed also in their reaction to the consequences of the crisis and the stimulus package already in 2009 . While growth rates from 2008 to 2009 practically did not differ (3.8 percent for urban employed and 3.4 percent for migrants) and the ratios of the regional distribtion of urban and urban private labor remained practically stable, migrants were strongly sensitive to both impacts: the ratio of migrant labor substantially decreased in the crisis hit east and increased in the stumulus supported central and western regions.

Table 3. Changes in the ratio of distribution of employment in urban, urban private and self- employment and migrants according to regions ( percent)

\begin{tabular}{|c|c|c|c|}
\hline Regions & & $\mathbf{2 0 0 8}$ & $\mathbf{2 0 0 9}$ \\
\hline \multirow{3}{*}{ Eastern } & $\mathrm{U}$ & 49.65 & 49.99 \\
\cline { 2 - 4 } & $\mathrm{Up}$ & 57.48 & 58.10 \\
\cline { 2 - 4 } & $\mathrm{M}$ & 71.0 & 62.5 \\
\hline \multirow{3}{*}{ Central } & $\mathrm{U}$ & 27.76 & 27.62 \\
\cline { 2 - 4 } & $\mathrm{Up}$ & 21.68 & 22.04 \\
\cline { 2 - 4 } & $\mathrm{M}$ & 13.2 & 17.0 \\
\hline \multirow{3}{*}{ Western } & $\mathrm{U}$ & 22.59 & 22.40 \\
\cline { 2 - 4 } & $\mathrm{Up}$ & 20.84 & 19.86 \\
\cline { 2 - 4 } & $\mathrm{M}$ & 15.4 & 20.5 \\
\hline Total & & 100.00 & 100.00 \\
\hline
\end{tabular}

Note: $\mathrm{U}=$ employed persons in urban units (including state-owned units, collectively owned units, cooperative units, limited liability corporations, shareholding corporation Ltd., units with fund from Hong Kong, Macao Taiwan and foreign funded units in urban area);

$\mathrm{Up}=$ employed persons in urban private enterprises and self-employed individuals;

$\mathrm{M}=$ migrant labor; according to our understanding

Since both $U$ and Up include urban migrant labor, changes in $U$ and Up are partly caused by changes in migrant flow

http://www.stats.gov.cn/english/statisticaldata/yearlydata/

NBS, China Migrants Monitoring Report 2009-2012

Consequently, owing to the social and economic background of high migrant labor mobility enhanced by their concentration on crisis-hit eastern regions in export oriented small and medium manufacturing enterprises, we hypothesized that migrant flow will react sensitively and rapidly to economic dynamics triggered by the dynamics of the crisis and to the priority investments of the stimulus package. In this manner, sectoral and regional consequences of the crisis on migrant flow will be reinforced rather than "neutralized" by the sectoral and 
regional priorities of the stimulus package.

\section{Data and methodology}

In more detail, the NBS migrant survey is a nationwide statistical dataset that was launched at the end of 2008 as a response to economic crisis. The aggregated statistics are published annually since 2009 in Survey and Monitoring Report of Migrant Workers. ${ }^{3}$ These aggregated statistics provide a unique chance to trace the crucial period of the 2008 crisis and reveal the impact of the stimulus package from the angle of migration. Unfortunately some of the necessary criteria from our point of view as size and ownership of enterprises where migrants work are completely missing. Still, several tendencies regarding the interdependency between economic developments and migrant flow can be revealed.

We also have benefitted from micro level rural-to-urban migrant household data (RUMiCI ${ }^{4}$.

\footnotetext{
${ }^{3}$ The survey is based on the NBS's rural household survey sample. The survey covers 31 provinces, autonomous regions and municipalities, 899 counties, 7500 villages and nearly 200,000 rural laborers. The introduction of the specific sampling method can be found in China Statistical Yearbook. Each year since 2009, the NBS would publish a report based on this survey. The latest report we use is for 2013. The report is published on the website of the NBS each year and from 2010 on, it was included as a chapter in China Development Report. ${ }^{4}$ The project was carried out in collaboration with Australian partners and focused on rural-to urban migrants in China and Indonesia (RUMiCI) (see Meng at al, 2010). Sampled cities and provinces in China are: Guangzhou, Shenzhen and Dongguan in Guangdong Province; Zhengzhou and Luoyang in Henan Province; Hefei and Bengbu in Anhui Province; Shanghai; Nanjing and Wuxi in Jiangsu Province; Hangzhou and Ningbo in Zhenjiang Province; Wuhan
} 
The survey was conducted in 15 cities in 9 provinces including both emigration region and immigration regions (Meng et al, 2010). We use the first two waves to explore micro-evidence of restructuring migration partly due to the crisis across regions, sectors and ownership. The first wave of RUMiC migrant survey was conducted in March-May 2008, just before the crisis and the second wave was conducted one year later. The period in between happened to overlap with the time when the Chinese economy was the most severely influenced by the crisis. The time period and the panel nature of the surveys allow us to explore the impact of the crisis on migrants in China using the first wave as a benchmark and the second wave as comparison. Despite the panel nature and the great effort made by the researchers to keep track of the surveyed migrant households, the attrition rate of originally sampled migrants was very high. Only 1821 out of the 5007 households in the 2008 survey could be tracked again in the 2009 survey. ${ }^{5}$ This means that by 2009, information about $2 / 3$ of the total sampled households was lost. This great loss is considered as "abnormal" for the following reasons: the median of the average time that the sampled household heads worked in one city was about 3.75 years. This implies that an annual attrition rate around $1 / 3$ should be expected as "normal" compared to the 63.63 percent. The "abnormal" attrition rate will be used as an indicator of the crisis impact on the possible restructuring of migrant distribution. A simple linear probability regression is used for this purpose. The survey's different concept in sampling methods and the large attrition rate through the years and the questions focusing

in Hubei Province; Chengdu in Sichuan Province; and Chongqing.

${ }^{5}$ Kong et al. (2010) tracked the original sample three times before the next survey -- in October 2008, December 2008 and February 2009 -- and found that only 48.77 percent of the original 5007 households could be tracked in February 2009. During the last tracking in 2009, when the survey was carried, they found the annual attrition rate as high as 63.63 percent. The attrition rate further increased in the following years. 
evidently on migrants rather than the priorities of the stimulus package unfortunately did not allow for tracking longitudinal developments from our point of view.

Owing to the lack of migrant data according to ownership and enterprise size, we shall constrain our calculations to regional and sectoral structural characteristics of migrant flow. Next we shall demonstrate to what extent migration was foredoomed to be sensitive to the crisis according to migrants' pre-crisis regional and sectoral distribution characteristics and the consequences these characteristics.

\section{The Impact of the Crisis on Migrant Flows}

\section{Migrants' Sensitivity to Crisis: Spatial and Sectoral Concentration}

Between late 2008 and early $2009^{6} 16$ percent of the 140 million migrants became suddenly unemployed. Regionally, the economic crisis directly hit overwhelmingly the eastern coast of the country where majority of export production was concentrated. By the end of 2008, 600 thousand enterprises were closed down, most of them in the coastal region (Kong et al., 2009, p. 237). According to place of origin, in 2008 migrants were spread more or less evenly

\footnotetext{
${ }^{6}$ The crisis had a multiplicative effect on families' living and social conditions since rural households use migration as one of their main sources of income, with remittances accounting for about 21 per cent of total rural income and 43 per cent of migrant-sending households' total income in 2007 (Demurger, 2012). Multiplicative is also the effect on sending families' age and gender distribution during crisis owing to returning migrants and also so-far migration routes, since ,... In 2007, 19 per cent of sending households had at least one migrant member working in the local county seat, 30 per cent had at least one migrant member working outside the county within the province, and 44 per cent had at least one migrant member working outside the province. Sending households ...have a higher share of adult males.. fewer elderly members ..., but more children below the age of 16.” (Demurger, 2012).
} 
among the three regions (ratios decreasing from east, to center and west). However, sensitivity of migrant labor to crisis should be traced according to the destination of migration where labor market should attract and absorb them. From this point of view the distribution of migrants is strongly uneven: in 2008, 71 percent of the migrants were working in the eastern provinces, only 13.2 percent in the central and 15.4 percent in the western provinces respectively (NBS report, 2008). Regional concentration of migrants is also reflected by the fact that 62.4 of migrants who returned to their hometown in late 2008 had worked in the eastern provinces, 16.15 percent in central, and 21.3 percent in western provinces. ${ }^{7}$ Not only the regional, but also the provincial concentration of those who returned was high in the east: 24.6 percent returned from Guangdong Province and 17.2 percent from Yangtze River Delta area. These two areas were the main destinations of migration and also the main exporting locations. Therefore, in view of the overlap of the regional concentration of exports, the main regional impact of the crisis and migrants' regional and municipal concentration, we expect that migrants were regionally highly sensitive, and lay-offs were also regionally concentrated. Regional concentration however at destination does not mean homogeneous regional origin. We do not have data on the distribution of migrants in 2008 at destination according to sending locations only from 2005, when micro-census was carried out. According to these

\footnotetext{
${ }^{7}$ Comparing migrants' regional distribution to the regional distribution of returned migrants, it seems that migrants in the eastern area were less likely to return, while migrants in western and central regions were more likely to return. However, these numbers are blurred by the fact that the figures on returned migrants were collected around Spring Festival, and many migrants in the eastern area faced high cost of returning to their hometown in center-west, discouraging their returning during Spring Festival. The crisis might have caused a higher return rate in 2008 compared with 2007, but unfortunately we do not have such comparable information.
} 
data in 2005, from all migrants 79.17 percent were concentrated to the eastern region. From all migrants of central and western origin 70.79 percent went to work to the eastern region and from all migrants located within the eastern region 59.24 percent were from central and western origin. Alternative data from 2008 reflect inter- and intra provincial migrant flow according to place of origin that show similarly large spatial mobility of central and western migrants. While in 2008 about 80 percent of migrants coming from eastern provinces remained in their own province, about 70 percent of those originating from central provinces and 63 per cent from western provinces had to leave to find work at other provinces. Concluding the above, the regional impact of the crisis hit directly those whose eastern origin and destination regionally overlapped, but it had regionally wide multiplicative effect from the point of view of those whose eastern destination was paired with central and western origin. Concentration and sensitivity was further intensified from another dimension: in 2008, 63 percent of migrants were working in large cities and provincial capitals (NBS survey, 2008-2011). This concentration meant larger than expected sensitivity to crisis, since high and over-the-average growth of GDP/cap cities were overwhelmingly surrounded and segregated by low and below-the-average GDP/capita city clusters where chances to find alternative jobs were low (see later on map 1/a). Thus, when crisis hit, not only large masses of migrants were suddenly on the streets but clustering characteristics of neighboring cities entrapped those masses.

Migrants were not only concentrated at regional, provincial and city level at the vesper of the crisis but also sectorally. In 2008, 50 percent percent of migrants worked in two sectors: 37.2 percent of the migrants worked in the manufacturing industry and 13.8 percent in the construction sector. Among all migrants who returned home at the start of the crisis 46.2 percent worked in manufacturing and 73.3 percent in construction. ${ }^{8}$ Cumulated regional,

\footnotetext{
${ }^{8}$ This two data however is distorted for at least two reasons: first, since return due to crisis
} 
municipal and sectoral concentration and lay-off of migrants allowed for mass grievances. This period saw the increase in the frequency and in the number of participants of mass demonstrations and the radicalization of requests (Cai Y, 2008, 2010).

In sum, aggregated data reveals that regional, provincial, municipal and sectoral distribution of migrants showed high sensitivity to regional and sectoral characteristics of the crisis that triggered similar characteristics in the restructuring of migrant flow.

\section{Consequences of Sensitivity: Characteristics of Migrant Mobility during the Crisis}

On micro level, crisis impact has been revealed from what arose as the methodological problem during the longitudinal survey in the RUMiCI project we have referred to in Section II: the high attrition rate (63 percent in the first year of the survey, compared to the expected $1 / 3$ "normal" attrition). We used the "abnormally" high attrition rate as an indicator of the crisis' negative impact on employment. We further assumed that dropping out of the sample means leaving the cities due to loss of job while those remaining in the sample either kept the same job or went to another one that could be tracked but did not leave the city. Then we can construct a dummy variable (Leave) indicating whether a surveyed household head can still be tracked or not in 2009 for each household and use it as dependent variable in a linear probability regression. ${ }^{9}$ However, since both sampling methods, locations and questions differ and lay-off at the end of 2008 accidentally overlapped with the two weeks national holiday when millions of migrants headed home, depending on financial capacity, distance from home, and sector and profile of the workplace. Second, the high percentage of migrants returning home from the construction sector crisis lay-offs not only coincide with the time of the national holiday but also with the seasonality in this sector when winter arrives. Data source: NBS, China Migrants Monitoring Report 2008, web link:

http://www.stats.gov.cn/was40/gitji_detail.jsp?channelid=33728\&record=41

${ }^{9}$ We use OLS for the linear probability regression since the coefficient is straightforward and 
in the micro survey compared to the macro level migrant statistics, results may not overlap, or can occasionally even contradict each other or that of those macro level economic tendencies despite correct analysis. Also the micro data and macro statistics are collected at different time points in 2009, which could also explain the likely inconsistence. Moreover, the macro trend was formed by both the reorientation of current migrants and the entrance of new migrants, while the regression can only pick up the former effect. Therefore, conclusions on the characteristics of sensitivity and mobility, and their high and low significance on micro level should be compared with great caution.

For the right hand side variables in the regression, we use the information of the household heads who were either wage-workers or self-employed from 16 to 59 years old in 2008. After dropping the observations with incomplete information, there are 4,650 household heads left in the sample. With the cleaned sample we focus on the regional, sectoral and ownership differences linked with the indicator. Besides the regional, sectoral and ownership variables of interest, personal characteristics, household characteristics, labor market experiences and selfreported willingness to stay are included in the regression to control for the potential mobility differences. The mean values of key variables are given in Table 4 and the regression results are shown in Table 5.

Table 4 shows significant differences in the distribution of regions, sectors and ownership in 2008 among the migrants who left the sample in 2009 and those who stayed. Migrants who left the sample are more concentrated in manufacturing and construction sector, in the private sector and in eastern cities, which is consistent with our hypothesis. This suggests that there may be correlations between the probability of leaving the sample and these factors. Then we turn to the regression results in Table 5 to see whether such correlations are significant after

easy to interpret. We have also done a probit regression and the marginal effects are quite similar. We don't report the probit results here for simplicity. 
controlling for other factors that may affect mobility.

Table 4. Mean value of key variables

\begin{tabular}{|c|c|c|c|}
\hline & All & Leave & Stay \\
\hline No. of Observations & 4650 & 2949 & 1701 \\
\hline Male & 0.692 & 0.679 & $0.715 * * *$ \\
\hline Age & 29.97 & 29.17 & $31.35 * * *$ \\
\hline Married dummy & 0.533 & 0.479 & $0.626 * * *$ \\
\hline Household size in city & 1.675 & 1.536 & $1.918 * * *$ \\
\hline Years of schooling & 9.320 & 9.310 & 9.338 \\
\hline Time since first migration (year) & 7.734 & 7.205 & $8.649 * * *$ \\
\hline Average No. of cities worked in one year & 0.404 & 0.444 & $0.333 * * *$ \\
\hline Willing to permanently stay in cities & 0.574 & 0.540 & $0.634 * * *$ \\
\hline Willing to stay only one year & 0.020 & 0.024 & $0.012 * * *$ \\
\hline Still Searching for other jobs & 0.265 & 0.282 & $0.236 * * *$ \\
\hline Years of current jobs & 3.503 & 3.113 & $4.180 * * *$ \\
\hline Have contract & 0.097 & 0.107 & $0.081 * * *$ \\
\hline $\begin{array}{l}\text { Wage workers (self-employed as reference } \\
\text { group) }\end{array}$ & 0.792 & 0.849 & $0.693 * * *$ \\
\hline Manufacture & 0.198 & 0.220 & $0.158 * * *$ \\
\hline Construction & 0.109 & 0.129 & $0.073 * * *$ \\
\hline SOE & 0.043 & 0.048 & $0.036^{*}$ \\
\hline Private & 0.406 & 0.426 & $0.371 * * *$ \\
\hline Foreign & 0.098 & 0.106 & $0.084 * *$ \\
\hline Size of Workplace: 5 employees or less & 0.314 & 0.266 & $0.396 * * *$ \\
\hline Size of Workplace: 6-20 & 0.201 & 0.213 & $0.182 * *$ \\
\hline Size of Workplace: 21-49 & 0.099 & 0.106 & $0.086 * *$ \\
\hline Size of Workplace: 50-99 & 0.079 & 0.089 & $0.061 * * *$ \\
\hline Size of Workplace: 100 and more & 0.308 & 0.326 & $0.275 * * *$ \\
\hline Within province migrants & 0.563 & 0.551 & $0.585 * *$ \\
\hline Hometown in eastern area & 0.269 & 0.289 & $0.234^{* *}$ \\
\hline Hometown in central area & 0.502 & 0.499 & 0.507 \\
\hline Hometown in western area & 0.229 & 0.212 & $0.259 * * *$ \\
\hline Work in eastern cities & 0.541 & 0.588 & $0.461 * * *$ \\
\hline Work in central cities & 0.297 & 0.276 & $0.335^{* * *}$ \\
\hline Work in western cities & 0.162 & 0.136 & $0.204 * * *$ \\
\hline
\end{tabular}

Notes: Asterisks stand form the significant level of t-test results of the mean differences between the two groups ( Leave/Stay). ***,**, and * stands for that mean equality can be rejected on 1 percent, 5 percent and 10 percent level, respectively.

In column (1) of Table 5, we can see that regional factors do matter in the probability of leaving the sample, but not according to migrants' hometown: (eastern/central, and western as reference groups) seem to have no influence on the probability of leaving the sample. The 
insignificance of hometown among those who left means similar probability of those leaving from the eastern cities according to place of origin. This is not surprising since the crisis or the labor market affect migrant workers based on where they are working, rather than where they are from. This is supported in Table 5 that shows that migrants working in eastern cities are more affected than those in central and western cities (eastern/central cities and western cities as reference group). Result is also consistent with the regional features of the impact of the crisis and Table 4 where we see that migrants who left the sample are more concentrated in manufacturing and construction sector, in private sector and in eastern cities. Migrants in eastern cities are more likely to leave suggests a regional redistribution of migrants. However, redistribution might have occurred also within the region, since migrants who live within the province are more likely to leave the sample. We suppose that the reasons are complex: both because eastern provinces were more strongly affected by the crisis, the proportion of migrants in the east who work in their hometown province is high, and probably because due to the lower migration costs and opportunity costs are increasing their chances to find other work. Thus, within-province migrants seem to be more affected by the crisis than the crossprovince migrants. This idea is supported by evident personal characteristics: compared to those who stay, among those who left higher is the probability (with high significance) of being more mobile, or less rooted in the destination place: those who are women, young, unmarried, with small local household, shorter time since the first migration, working in several cities within a year, with no intention to settle, those who were working shorter in their actual workplace, have contract, seemingly being more competitive or working in manufacture), are wage workers, and working in relatively small enterprises (with 6-100 employees). The regression shows that intra-provincial migrants are more likely to leave than those who migrated among provinces. These results do not contradict the macro results of the following years' rising proportion of within province migration detected by national macro 
statistics later in Table 6 in all eastern, central and western regions.

Sectors are also important. Compared with those in all other sectors, migrants both in manufacturing and in construction are negatively affected by the crisis, and construction migrants are more affected than manufacturing migrants. Similar results were revealed on macro level when returning migrants from construction sector were overrepresented compared to migrants' sectoral distribution. As we have mentioned before, the overrepresentation of construction workers in returning migrants may also be the result of seasonal stop of construction projects, especially in northern China. In term of the probability of leaving the sample, migrants in enterprises of different ownership show no differences. Migrants in relatively large enterprises (100 employees or more, as reference group, omitted in the regression) were less affected than those in smaller enterprises (Size of Workplace: 5 employees or less, 6-20, 21-40 and 50-99), perhaps due to firm's the better ability to resist external shocks, lower flexibility and higher probability to get supported. The signs of these variables are consistent with our intuitive expectations.

Besides the average effects, we could also expect the heterogeneity in the coefficients of sectoral variables across regions since the crisis hit the economy unevenly. In column (2), we added interaction terms between working locations dummies and sector dummies and ownership dummies. The results support the heterogeneity across regions. The significantly negative coefficient of manufacturing dummy in column (2) shows that in western cities, migrants in manufacturing are less affected by the crisis, have more stable jobs than migrants in other sectors. More precisely, the probability to leave in the manufacturing industry is higher in the eastern but even higher in the central cities compared to the western cities. The positive coefficients of the two interaction terms (Manufacture*Work in eastern cities, Manufacture*Work in central cities) suggest that the major effect of crisis on migrant workers in manufacturing sector happened in eastern and central cities. The regional differences 
reflected in the construction variables (Construction, Construction*Work in eastern cities, Construction *Work in central cities) tell regionally different stories. On average, construction workers were hurt by the crisis, but construction workers in central cities were less hurt than those in eastern and western cities, though much less hurt in eastern than western cities. The interaction terms suggest that along with the redistribution of migrants favoring the central and western area, this is also a sectoral redistribution: migrants working in the manufacturing sector are relatively decreasing in the eastern region but even more in the central region and migrants in construction sector are growing relatively faster in the central and eastern region. Results of regional-sectoral micro data in case of manufacturing and construction do not overlap completely with our macro-level data. For example, we have expected that migrant data will show that export-oriented manufacturing enterprises in the coastal cities were hit harder than their counterparts in inland areas. However, data seemingly reflect a more complex tendency that would need more information on export, size, profile ownership and bankruptcy of enterprises located in the different regions within migrant data and also city choice and sampling might have a strong influence on the results.

Table 5. Leaving or Staying in the Survey: Linear Probability Regression

(1) (2)

VARIABLES

Leave

Leave

Male

Age

Age square

Married dummy

Household size in city

Years of schooling

Years since first migration

$\begin{array}{ll}-0.0242 & -0.0217 \\ (-1.564) & (-1.402) \\ -0.0142 * * & -0.0134 * * \\ (-2.457) & (-2.327) \\ 0.000182 * * & 0.000169 * * \\ (2.316) & (2.151) \\ -0.0112 & -0.00883 \\ (-0.488) & (-0.386) \\ -0.0326 * * * & -0.0325 * * * \\ (-3.531) & (-3.524) \\ -0.0119 * * * & -0.0119^{* * *} \\ (-3.832) & (-3.828) \\ -0.000352 & -0.000244\end{array}$

$-0.0242$

$(-1.402)$

$(-2.327)$

0.000169 **

$-0.00883$

$(-0.386)$

$(-3.524)$

$(-3.828)$

$-0.000244$ 
Average No. of cities worked in one year
Willingness of permanent stay in cities
Willingness to stay only one year
Still Searching for other jobs
Years at current job
Have a contract
$\begin{aligned} & \text { Wage workers (self-employ as reference } \\ & \text { group) }\end{aligned}$

$(-0.236)$

$(-0.164)$

0.00852

0.00856

(1.357)

(1.365)

-0.0319 **

$-0.0311 * *$

$(-2.215)$

$(-2.163)$

0.0500

0.0611

(1.001)

(1.223)

0.0281 *

0.0250

(1.777)

(1.580)

$-0.00696 * * *$

$-0.00740 * * *$

$(-3.593)$

(-3.810)

0.0321

0.0269

(1.357)

(1.132)

$0.0843 * * *$

$0.0854 * * *$

Manufacture

(3.250)

$0.0731 * * *$

(3.291)

$-0.210 * *$

(3.414)

(-2.232)

Construction

$0.152 * * *$

$0.256^{* * * *}$

(4.619)

$-0.0716$

$(-0.822)$

0.0363

Private

0.0234

(0.651)

0.00737

(1.003)

Foreign \& Joint Venture

$(0.454)$

$-0.208$

$-0.0105$

$(-1.575)$

Size of Workplace: 5 employees or less

$(-0.378)$

0.0251

$(0.726)$

(1.011)

Size of Workplace: 6-20

0.0359

$0.0435 *$

$(1.622)$

(1.960)

Size of Workplace: 21-49

0.0168

0.0251

$(0.631)$

Size of Workplace: 50-99

$0.0570 * *$

$(0.943)$

(2.033)

$0.0630 * *$

Within province migrants

$0.0409 * *$

(2.243)

$0.0388 * *$

(2.162)

(2.055)

Hometown_eastern

$-0.00298$

$-0.00421$

$(-0.100)$

Hometown_central

$-0.00109$

$(-0.0398)$

Work in eastern cities

$0.152 * * *$

$(-0.141)$

$-0.00192$

$(-0.0707)$

(4.511)

$0.173 * * *$

Work in central cities

$0.0632 *$

(4.298)

(1.896)

0.0594

(1.483)

Manufacture*Work in eastern cities

$0.276 * * *$

(2.852)

Manufacture*Work in central cities

$0.338 * * *$

(3.336)

$-0.119 *$

Construction*Work in eastern cities

(-1.877)

$-0.139 * *$

$(-2.071)$

$-0.0583$

$(-1.408)$

0.00371

Private *Work in central cities

$(0.0821)$ 
SOE*Work in eastern cities

SOE *Work in central cities

Foreign \& Joint Venture *Work in eastern cities

Foreign \& Joint Venture *Work in central cities

Constant

Observations

R-squared

$\mathrm{t}$-statistics in parentheses

$* * * \mathrm{p}<0.01, * * \mathrm{p}<0.05, * \mathrm{p}<0.1$
0.125

0.121

(1.099)

0.209

0.154

$(1.052)$

$0.830 * * *$

(7.913)

4,650

0.085

To sum up, the regional and sectoral sensitivity of migrants to crisis and the regional and sectoral characteristics of migrant flow derived from micro evidence of the RUMIC survey seams to roughly support each other and our hypothesis about the impact of crisis on migrants. The correlations between the crisis indicator and regional, and sectoral suggest that the crisis played a role in restructuring the migration distribution across regions and sectors through its unequal effect across regions and sectors. However, we could not prove that macro level regional and sectoral sensitivity to crisis is clearly matches the regional and sectoral behavior of job leaving of migrants during the first year of the crisis based on the empirical survey.

Regression analysis of micro level survey would have been ideal to reveal the regional and sectoral distributional consequences of migrant sensitivity to crisis in case survey data sampling principles would overlap those of aggregated database. However, sampling differences in the available survey did not provide this ideal situation. Thus, we have to admit, that several initial problems might have distorted the results. Distortions might have emerged due to different motivations of city selection (the survey contains cities that are overwhelmingly origin or destination of migration, as opposed to national level representativeness of all administrative levels in the national statistics); also differences of sampling within cities emerge and a number of unknown complexity of reasons of the 
attrition rate; we interpreted the attrition as lay-offs at a time when the survey overlaps with the national holiday when many migrants leave anyway. All these factors leave us with high uncertainty about the usability of the survey for our purposes. Moreover, such a regression has other flaws by relying on the link between migrants leaving the sample and affected by the crisis. The link is only partially valid and thus probably weak. We tried to control for factors that may affect households' mobility, but there could still be omitted variables affecting potential mobility that correlates with regions or sectors, the regression results can be biased. Our ability to correct these flaws was limited by available data. Therefore, we cannot control the reasons why some results that should be significant are not too significant, or why some times results do not overlap with our macro statistical results (e.g. construction and center more attained by the crisis than east and the manufacturing sector) to reveal empirically the characteristics of migrant mobility.

\section{The impact of the stimulus package and its priorities on migrant flows}

\section{Impact on migrant employment}

The prevalence and propagation of the crisis was uncertain, and so were the chances of recovery and its impact on party legitimacy strictly intertwined with the economy (Csanádi, 2006, 2012; Buckley, 2009; Cai and Chan, 2009; Demick, 2008; Chan, 2010; Kong et al, 2009; Meng et al, 2010; Wong, 2008; Charter, 2008; Chen N.; 2009, Yu 2009). However, uncertainty soon withered away since the dramatic set-back proved to be short-lived. From the second quarter of 2009 exports began to recover after the primary shock, loans skyrocketed and investments accelerated already in 2009. Although GDP growth was slower compared to export growth but it accelerated to 10.4 by 2010 and also FDI got impetus after the shrinkage in 2009 (Table 1 and Table 2).

Thanks to the prompt implementation of the stimulus package and to the revival and regional 
spreading of export activity, migrant unemployment soon dropped from 16 percent to 3.4 percent from mid-2009 (Cai and Chan, 2009, 521). This is the reason why the 16 percent unemployment rate during the few months at the peak of the crisis is not visible in case of year-on-year calculations. The labor demand generated by the stimulus plan not only quickly compensated the impact of the crisis but also kept the demand for migrants growing well above their number before the crisis. The rate of growth in migrant number was the highest in 2010, just as the rate of overall employment in urban area, though the growth rate of migrants was higher (Table 6). This period coincided with the doubling of investment rate compared to 2009 growth and the almost hundred percent growth of loans in 2009 (see Table 2)

Table 6 Growth rate of migrant and urban employment ( percent) ${ }^{10}$

\begin{tabular}{|l|l|l|l|l|l|}
\hline & 2008 & 2009 & 2010 & 2011 & 2012 \\
\hline
\end{tabular}

\footnotetext{
${ }^{10}$ Here we use different English translation terms from the NBS. Nonfarm Rural Labor is the same as the NBS definition of "migrant workers", which includes those who are employed outside their villages and towns for more than six months in the year (Migrants, or in NBS term, "Home leaving migrant workers") and those who do non-agricultural work in their villages and towns for more than six months in the year(Local nonfarm, or in NBS term, "local migrant workers"). We use these different terms since we believe that it makes more sense to onlt refer those actual move out their hometown as migrants and also to avoid confusion since the NBS terms have the word "migrant" in them. All discussion with the NBS migrant report statistics follow the term definitions above.
} 


\begin{tabular}{|l|c|c|c|c|c|}
\hline Nonfarm Rural Labor & & 1.9 & 5.4 & 4.3 & 4.0 \\
\hline 1. Migrants & $(-16.0)$ & 3.50 & 5.52 & 3.44 & 2.98 \\
\hline 2. Local Nonfarm & & -0.7 & 5.2 & 5.9 & 5.5 \\
\hline $\begin{array}{l}\text { Urban Employed } \\
\text { Persons }\end{array}$ & 4.47 & 3.80 & 4.10 & 3.54 & 3.31 \\
\hline
\end{tabular}

Note: Source: NBS, China Migrants Monitoring Report 2009-2012. 2008 data is obtained from the 2009 report. Web link for 2012 report: http://www.stats.gov.cn/tjfx/jdfx/t20130527_402899251.htm All following tables concerning China Migrants Monitoring Report 2012 share the same source above. NBS, China Statistical Yearbooks 2012, Table 4-2.

During the researched period the estimated number of migrants increased by almost 20 million: from 140.41 million in 2008 to 158.63 million in $2011 .^{11}$ The remarkable labor market impact of the stimulus package is reflected in the research report of the National Development and Reform Commission (NDRC). According to the report, investments created 5.6 million permanent jobs and 50 million temporary workplaces (Bloomberg, 2010 June $15)^{12}$

\section{Regional impact on migrant flow within and across regions}

As investments created new jobs and intensified migrant flow so did investment priorities of

11 China's migrants monitoring report (NMS) 2012, also in China Development Report http://www.stats.gov.cn/tjfx/jdfx/t20130527_402899251.htm. Other sources as ChinaCIA The world Factbook (2013) https://www.cia.gov/library/publications/the-worldfactbook/geos/ch.html estimate the number of migrant growth much larger, to 100 million, but I assume there is a category mistake in 2011 that does not overlap that of in 2008. In 2008 it considers migrants amounting to 140.41 million, while in 2011 considers non-farm rural laborers (migrants plus local rural workers) 252.78 million.

12 China May See 'Severe' Job Losses Next Year As Stimulus Unwinds, CICC Says http://www.bloomberg.com/news/2010-06-16/china-may-see-severe-job-losses-as-stimulusprojects-completed-cicc-says.html, 2010 June 15 
the stimulus package, the adaptation of the private sector in construction and manufacturing influence the thus-far regional and sectoral distribution of migrants. Table 6 shows a steady decline in the share of cross-province migrants. By 2010 the ratio of those who stayed and migrated out became practically even, and by 2011 the earlier tendencies begun to reverse, higher became the ratio of those who stayed in their hukou province ${ }^{13}$ than that of those leaving. The tendency that began with the crisis was reinforced by the impact of the regional preferences of the stimulus package: Owing to regional economic developments, migrants first were forced by the crisis, later preferred to find job within their own hukou province rather than migrate outside the province.

Table 7 Regional distribution of migrants migrating within and across provinces ( percent)

\begin{tabular}{|l|c|c|c|c|c|c|c|c|c|c|}
\hline & \multicolumn{2}{|c|}{2008} & \multicolumn{2}{c|}{ 2009 } & \multicolumn{2}{c|}{ 2010 } & \multicolumn{2}{c|}{2011} & \multicolumn{2}{c|}{2012} \\
\hline & $\begin{array}{c}\text { Within } \\
\text { Prov. }\end{array}$ & $\begin{array}{c}\text { Across } \\
\text { Prov. }\end{array}$ & $\begin{array}{c}\text { Within } \\
\text { Prov. }\end{array}$ & $\begin{array}{c}\text { Across } \\
\text { Prov. }\end{array}$ & $\begin{array}{c}\text { Within } \\
\text { Prov. }\end{array}$ & $\begin{array}{c}\text { Across } \\
\text { Prov. }\end{array}$ & $\begin{array}{c}\text { Within } \\
\text { Prov. }\end{array}$ & $\begin{array}{c}\text { Across } \\
\text { Prov. }\end{array}$ & $\begin{array}{c}\text { Within } \\
\text { Prov. }\end{array}$ & $\begin{array}{c}\text { Across } \\
\text { Prov. }\end{array}$ \\
\hline National & 46.7 & 53.3 & 48.8 & 51.2 & 49.7 & 50.3 & 52.9 & 47.1 & 53.2 & 46.8 \\
\hline Eastern & 79.7 & 20.3 & 79.6 & 20.4 & 80.3 & 19.7 & 83.4 & 16.6 & 83.7 & 16.3 \\
\hline Central & 29.0 & 71.0 & 30.6 & 69.4 & 30.9 & 69.1 & 32.8 & 67.2 & 33.8 & 66.2 \\
\hline Western & 37.0 & 63.0 & 40.9 & 59.1 & 43.1 & 56.9 & 43.0 & 57.0 & 43.4 & 56.6 \\
\hline
\end{tabular}

Source: NBS, China Migrants Monitoring Report 2009-2012

This trend is indirectly supported by by the level, the dynamics and the spatial clustering of prefecture level GDP/capita. Before crisis (Map. 1/a) segregated spots of generally provincial capital cities with high level and above average growth GDP/cap were surrounded by extended clusters of low level and below average growth GDP/capita prefectures. This configuration has changed on Map 1/b owing to the impact of the stimulus package: the

\footnotetext{
${ }^{13}$ Hukou province means the province where the migrant's home-town is located and his/her registration belongs to.
} 
number of cities and provinces with high-level and above average growth of GDP/capita increased and large cities and provincial capitals became surrounded by increasing number of low level but above the average GDP/capita cities. The transformed spatial configuration suggests the broader chances of migrants to be employed within their hukou provinces.

Map 1 Changeing regional chances of migrants to find jobs

Map 1/a Regional chances of migrants to find job in 2000-2005

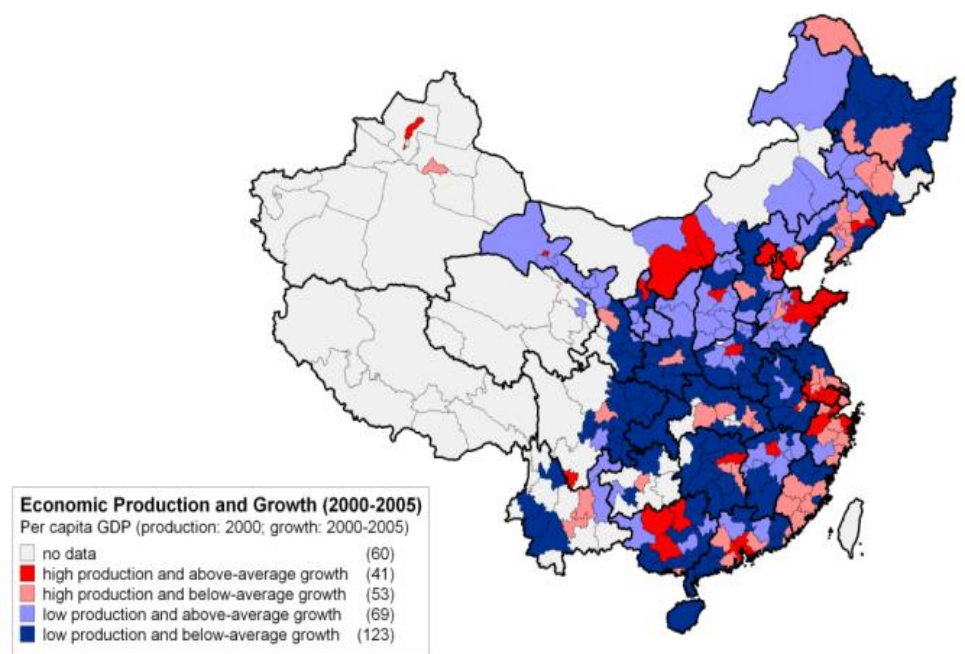

Map 1/b Regional chances of migrants to find job in 2008-2010 


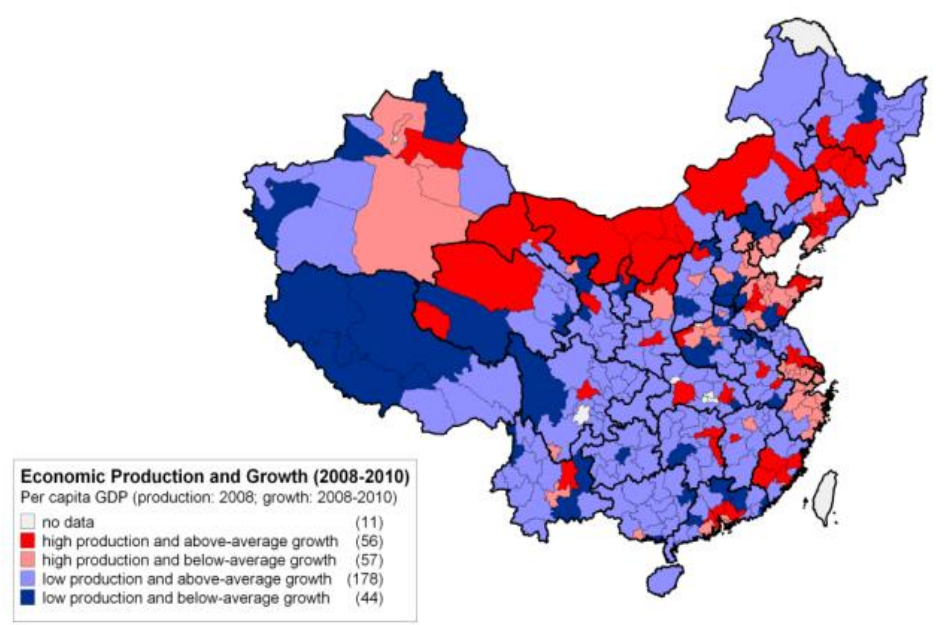

Despite the increase in the number of migrants, and the widespread economic growth around main industrial sites migrants' concentration to large cities did not change, instead, somewhat even grew at municipalities and provincial capitals. This is because job opportunities brought by the stimulus package benefited mainly large cities where industries, infrastructure building and services concentrate.

Disaggregated results in Table 7 by show regional differences: the overwhelming majority of those with hukou in the east steadily migrated within their own province throughout the researched period. However, supposedly due to the crisis and the regional investment preferences of the stimulus package, the ratio of those who chose to remain within their hukou province increased the most in the traditionally major source of outmigration: in the western provinces. It also slightly but steadily increased both in eastern and central regions.

Differences emerge in the years when the ratio of those who remained in their own hukou province increased the most: in the west the radical increase occurred from 2008 throughout 2010, in the center in a slower pace from 2010 throughout 2012, while in the east, the shortest in time from 2010 to 2011. The reasons of different time and length of growth ratio might be related to the different periods of investment growth and migrant labor demand in the 
different regions. We do not have relevant data on this issue. Whether this restructuring within regions remains persistent, we should examine a longer period.

As a result of regional developmental preferences and higher ratio of those who remained in their own province, in 2009 compared with 2008, migration distances for those at central and western regions shrank since these latter absorbed larger ratio of migrants, both in absolute numbers and relatively.

\section{Regional impact on migrant flow towards and from different regions}

The new dominance of intra-provincial migration over interprovincial migration in the center and west suggest the shrinkage of migration routes also in another dimension: the decline of the persistent attracting dominance of the east. This decline may be detected through the dynamics of the migrant traffic (flow to and flow from) according to regions (Table 8.)

Table 8. Scale and share of migrants from 2008 to 2012 according to original location and destination of migrants by region

\begin{tabular}{|c|c|c|c|c|c|c|c|c|c|c|c|c|c|}
\hline & ALL & \multicolumn{4}{|c|}{ EAST } & \multicolumn{4}{c|}{ CENTER } & \multicolumn{4}{|c|}{ WEST } \\
\hline & & F & T & F & T & F & T & F & T & F & T & F & T \\
\hline & mil & $\begin{array}{c}\text { perce } \\
\text { nt }\end{array}$ & $\begin{array}{c}\text { perce } \\
\text { nt }\end{array}$ & mil & mil & $\begin{array}{c}\text { perce } \\
\text { nt }\end{array}$ & $\begin{array}{c}\text { perce } \\
\text { nt }\end{array}$ & mil & mil & $\begin{array}{c}\text { perce } \\
\text { nt }\end{array}$ & $\begin{array}{c}\text { perce } \\
\text { nt }\end{array}$ & mil & mil \\
\hline $\begin{array}{c}\mathbf{2 0 0} \\
\mathbf{8}\end{array}$ & $\begin{array}{c}140 . \\
41\end{array}$ & 37.6 & 71.0 & $\begin{array}{c}52.7 \\
9\end{array}$ & $\begin{array}{c}99.6 \\
4\end{array}$ & 32.7 & 13.2 & $\begin{array}{c}45.9 \\
1\end{array}$ & $\begin{array}{c}18.5 \\
9\end{array}$ & 29.7 & 15.4 & $\begin{array}{c}41.7 \\
0\end{array}$ & $\begin{array}{c}21.6 \\
5\end{array}$ \\
\hline $\begin{array}{c}\mathbf{2 0 0} \\
\mathbf{9}\end{array}$ & $\begin{array}{c}145 \\
33\end{array}$ & 31.9 & 62.5 & $\begin{array}{c}46.3 \\
6\end{array}$ & $\begin{array}{c}90.7 \\
6\end{array}$ & 36.5 & 17.0 & $\begin{array}{c}53.0 \\
5\end{array}$ & $\begin{array}{c}24.7 \\
7\end{array}$ & 31.6 & 20.2 & $\begin{array}{c}45.9 \\
2\end{array}$ & $\begin{array}{c}29.4 \\
0\end{array}$ \\
\hline $\begin{array}{c}\mathbf{2 0 1} \\
\mathbf{0}\end{array}$ & $\begin{array}{c}153 . \\
35\end{array}$ & 31.8 & & $\begin{array}{c}48.7 \\
7\end{array}$ & & 36.6 & & $\begin{array}{c}56.1 \\
3\end{array}$ & & 31.6 & & $\begin{array}{c}48.4 \\
6\end{array}$ \\
\hline $\begin{array}{c}\mathbf{2 0 1} \\
\mathbf{1}\end{array}$ & $\begin{array}{c}158 . \\
63\end{array}$ & 31.6 & & $\begin{array}{c}50.1 \\
3\end{array}$ & & 36.6 & & $\begin{array}{c}58.0 \\
6\end{array}$ & & 31.8 & & $\begin{array}{c}50.4 \\
4\end{array}$ \\
\hline $\begin{array}{c}\mathbf{2 0 1} \\
\mathbf{2}\end{array}$ & $\begin{array}{c}163 . \\
36\end{array}$ & 31.5 & & $\begin{array}{c}51.4 \\
6\end{array}$ & & 36.7 & & $\begin{array}{c}59.9 \\
5\end{array}$ & & 31.8 & & $\begin{array}{c}51.9 \\
5\end{array}$ \\
\hline
\end{tabular}

Note: $\mathrm{F}=$ Coming From; $\mathrm{T}=$ going To; All those coming from $(\mathrm{F})=100$; all those going to $(\mathrm{T})=$ is nearly 100 yearly. The rest (e.g. 0.4 in 2008 and 0.3 in 2009) is the share of those oversea migrants.

Source: NBS, China Migrants Monitoring Report 2009-2012

Sensitivity of migrants was higher in the east: both due to the crisis and the opportunities in 
the central and western regions, in absolute numbers, fewer migrants remained in their own location in 2009 compared to 2008. Employment in the east decreased also relatively compared with the remaining migrant population at central and western regions, which is consistent with the micro-level findings. However, from the source aspect, the decline of the share of the eastern area happened largely in 2009, at the peak of the crisis when the absolute numbers also decreased while migrants coming from central and western area increased both in shares and absolute numbers in 2009. The crisis drove migrants from eastern area back to their home town and migrants from central and western countryside were attracted to cities nearby since there were more job opportunities in central and western cities due to the increased investments. Still, the share of those leaving their hukou province in the central and the western regions is higher than that of those coming both to these regions.

Now let us call the changing ratios of coming and leaving migrants in each region as "traffic" that may slow down and speed up. Slow down occurs if percentrages of leaving and coming drop, speed up occurs if both percentages grow. Differences in percentages will define if the given region is net exporter or importer of migrants. Based on the table, traffic slowed down in the east while the percentage of those leaving dropped faster (net exporter); traffic increased in the center at equal pace among those coming and leaving; meanwhile, the increase in the west reflected a higher pace among those coming than of those leaving (net importer).

\section{Impact on sectoral and sectoral-regional reorientation of migrant flow}

Unfortunately migrant statistical data do not include a clear sectoral distribution only the larger aggregation of non-farm rural laborers that to some extent distorts migration figures with those local rural workers who have jobs within their original township but do not migrate out. However, even in this distorted form we can detect the slow but steady increase of the 
ratio of non-farm labor in the construction sector at the expense of the manufacturing sector throughout 2012 (Table 9). This happened despite the fact that the share of non-farm rural workers in the manufacturing sector remained the double of those in the construction sector.

Table 9. Sectoral Distribution of Nonfarm Rural Laborers from 2008-2011 ( percent)

\begin{tabular}{|c|c|c|c|c|c|}
\hline & $\mathbf{2 0 0 8}$ & $\mathbf{2 0 0 9}$ & $\mathbf{2 0 1 0}$ & $\mathbf{2 0 1 1}$ & $\mathbf{2 0 1 2}$ \\
\hline Manufacturing & 37.2 & 36.1 & 36.7 & 36.0 & 35.7 \\
\hline Construction & $\mathbf{1 3 . 8}$ & $\mathbf{1 5 . 2}$ & $\mathbf{1 6 . 1}$ & $\mathbf{1 7 . 7}$ & $\mathbf{1 8 . 4}$ \\
\hline $\begin{array}{c}\text { Transportation, } \\
\text { storage \& post }\end{array}$ & 6.4 & 6.8 & 6.9 & 6.6 & 6.6 \\
\hline Wholesale \& retail & 9.0 & 10.0 & 10.0 & 10.1 & 9.8 \\
\hline Hotel \& catering & 5.5 & 6.0 & 6.0 & 5.3 & 5.2 \\
\hline Services & 12.2 & 12.7 & 12.7 & 12.2 & 12.2 \\
\hline Others & 15.9 & 13.2 & 11.6 & 12.1 & 12.1 \\
\hline Total & 100.0 & 100.0 & 100.0 & 100.0 & 100.0 \\
\hline
\end{tabular}

Source: NBS, China Migrants Monitoring Report 2009-20112

As to the sectoral dynamics: the share of non-farm employment in manufacturing over 2009 decreased by 1.1 percentage point, then slightly increased in 2010 and practically remained stagnant the next two years. The growing share of employment of non-farm rural laborers in construction follows the tendency of increasing share of construction sector in the GDP. In 2008 it was 6 percent, increased to 6.6 percent in 2009 and 2010, and kept rising to 6.8 percent in 2011 and 2012. Given the statistical figures of the first half of 2013, we suppose that the share of construction will be even higher. ${ }^{14}$ Since the majority of construction workers

\footnotetext{
${ }^{14}$ Data source: construction shares in GDP of 2008-2011 were collected from the China Statistical Yearbook 2012 and information of 2012 and first half of 2013 was collected and calculated from following NBS web links:

http://www.stats.gov.cn/tjgb/ndtjgb/qgndtjgb/t20130221_402874525.htm
} and http://www.stats.gov.cn/tjfx/jdfx/t20130715_402911015.htm 
are migrants, the growing share of migrants working in construction reflected the expanding trend of the construction sector (Csanádi, 2013). Even after 2009 and 2010 the rate of employment in the construction sector shows no sign of shrinking. The stimulus package may have triggered the construction "boom" and exert a relative long impact on the sectoral distribution of migrants.

The regional-sectoral distribution of non-farm laborers proves to be more differentiated; however, data is available only for 2010, 2011 and 2012 (Table 10). The share of those working in manufacturing declined in the east, somewhat increased in the central region and stagnated in the western region. In turn, in the construction sector non-farm employment continuously but modestly increased in all regions, but the highest increase in the share of construction was experienced in the central region from 2010 to 2012 followed by the western and eastern region respectively.

This tendency matches the regional impact of priority developments and the growth of employment in the stimulus-prioritized construction sector in all three regions (Csanádi, 2013) and reinforces the tendency of the crisis regarding its impact on the regional and sectoral migrant routes in manufacturing and compensates it in the earlier constraining impact on construction.

Table 10. Sectoral Distribution of Nonfarm Rural Laborers in 2010-2011 by Region ( percent)

\begin{tabular}{|c|c|c|c|c|c|c|c|c|c|c|c|c|}
\hline & \multicolumn{3}{|c|}{ All } & \multicolumn{3}{c|}{ East } & \multicolumn{3}{c|}{ Center } & \multicolumn{3}{c|}{ West } \\
\hline & $\mathbf{2 0 1 0}$ & $\mathbf{2 0 1 1}$ & $\mathbf{2 0 1 2}$ & $\mathbf{2 0 1 0}$ & $\mathbf{2 0 1 1}$ & $\mathbf{2 0 1 2}$ & $\mathbf{2 0 1 0}$ & $\mathbf{2 0 1 1}$ & $\mathbf{2 0 1 2}$ & $\mathbf{2 0 1 0}$ & $\mathbf{2 0 1 1}$ & $\mathbf{2 0 1 2}$ \\
\hline Manufacturing & 36.7 & 36.0 & 35.7 & 46.2 & 44.8 & 44.6 & 22.4 & 23.0 & 23.2 & 15.0 & 15.4 & 15.4 \\
\hline Construction & $\mathbf{1 6 . 1}$ & $\mathbf{1 7 . 7}$ & $\mathbf{1 8 . 4}$ & $\mathbf{1 2 . 2}$ & $\mathbf{1 3 . 4}$ & $\mathbf{1 3 . 9}$ & $\mathbf{2 0 . 5}$ & $\mathbf{2 4 . 7}$ & $\mathbf{2 5 . 5}$ & $\mathbf{2 6 . 1}$ & $\mathbf{2 7 . 4}$ & $\mathbf{2 8 . 4}$ \\
\hline $\begin{array}{c}\text { Transportation, } \\
\text { storage and } \\
\text { post }\end{array}$ & 6.9 & 6.0 & 6.6 & 5.8 & 5.5 & 5.6 & 8.5 & 8.1 & 8.2 & 9.3 & 9.3 & 8.8 \\
\hline $\begin{array}{c}\text { Wholesale and } \\
\text { retail }\end{array}$ & 10.0 & 10.1 & 9.8 & 8.6 & 8.7 & 8.5 & 13.1 & 13.1 & 12.6 & 11.9 & 12.5 & 11.9 \\
\hline $\begin{array}{c}\text { Hoteling and } \\
\text { catering }\end{array}$ & 6.0 & 5.3 & 5.2 & 5.0 & 4.5 & 4.4 & 7.0 & 5.9 & 5.8 & 8.5 & 7.3 & 7.6 \\
\hline Services & 12.7 & 12.2 & 12.2 & 12.1 & 12.3 & 12.4 & 13.5 & 11.4 & 11.3 & 14.1 & 12.2 & 12.1 \\
\hline
\end{tabular}




\begin{tabular}{|c|c|c|c|c|c|c|c|c|c|c|c|c|}
\hline Others & 11.6 & 12.7 & 12.1 & 10.1 & 10.8 & 10.6 & 15.0 & 13.8 & 13.4 & 15.1 & 15.9 & 15.8 \\
\hline Total & 100.0 & 100.0 & 100.0 & 100.0 & 100.0 & 100.0 & 100.0 & 100.0 & 100.0 & 100.0 & 100.0 & 100.0 \\
\hline
\end{tabular}

\section{Social consequences of-regional-sectoral characteristics of migrant flow}

Regional sectoral restructuring of migrant flow due to the cumulated sectoral and regional impact of the crisis and the stimulus priorities had corresponding social consequences. Incomes increased steadily in all sectors, supposedly as a result of increased labor demand, owing to regional and sectoral preferences of the stimulus package, and adapting market reactions to it. Still, the highest incomes in absolute number all over the years and the highest growth in 2011 are shown in the transportation and construction sectors (Table 11). However, construction sector preferred by the stimulus package carried the highest risks in employment without contract in 2009 presumably owing to the large pool of migrants attracted to the construction sector. In 2009, 74 percent of migrants working in the construction sector compared to the average 57.2 percent of migrants did not have a contract.

Table 11. Average Monthly Income growth of Migrants (based on 2008 prices) and the share of those with no contract by sector

\begin{tabular}{|l|l|l|l|l|l|l|}
\hline & $\begin{array}{l}\text { Monthly } \\
\text { income } \\
\text { Growth } \\
\text { percent }\end{array}$ & $\begin{array}{l}\text { NO } \\
\text { contract } \\
\text { percent }\end{array}$ & $\begin{array}{l}\text { Monthly } \\
\text { income } \\
\text { Growth }\end{array}$ & $\begin{array}{l}\text { NO } \\
\text { contract } \\
\text { percent }\end{array}$ & $\begin{array}{l}\text { Monthly } \\
\text { income } \\
\text { Growth } \\
\text { percent }\end{array}$ & $\begin{array}{l}\text { NO } \\
\text { contract } \\
\text { percent }\end{array}$ \\
\hline Manuf. & 6.01 & 49.3 & 15.07 & 52.3 & 15.18 & 49.6 \\
\hline Constr. & 6.65 & 74.0 & 15.95 & 70.9 & 16.13 & 73.6 \\
\hline $\begin{array}{l}\text { Transp., } \\
\text { storage } \\
\text { \& post }\end{array}$ & 6.38 & Missing & 13.31 & Missing & 20.50 & Missing \\
\hline $\begin{array}{l}\text { Wholesale } \\
\text { \& retail }\end{array}$ & 4.01 & 66.0 & 15.14 & 64.7 & 11.89 & 60.9 \\
\hline
\end{tabular}




\begin{tabular}{|l|l|l|l|l|l|l|}
\hline $\begin{array}{l}\text { Hotel } \\
\text { \& catering }\end{array}$ & 8.90 & 65.2 & 15.71 & 65.7 & 13.44 & 64.6 \\
\hline Services & 5.41 & 63.9 & 15.33 & 62.8 & 13.97 & 61.4 \\
\hline Average & 6.49 & 57.2 & 15.49 & 58 & 14.99 & 56.2 \\
\hline
\end{tabular}

Source: NBS, China Migrants Monitoring Report 2009-2011

Those with no (written) contract in the manufacturing sector never reached the hight of the same in the construction and remained always below the average, while in construction this ratio was always the highest presumably owing to the high turnover of those working in this sector. ${ }^{15}$ In 2011 those with no contract in manufacturing declined parallel to all other sectors' no-contract ratio.

Priorities brought about faster income increase in the western and central regions in 2009, narrowing the so far prevailing regional migrant income gap (Table 12).

\footnotetext{
${ }^{15}$ This fact may be explained also by the special conditions the workers are hired in the construction sector. In most cases, the construction companies do not employ any construction worker directly. They will find a labor company to provide workers. The labor companies often have connection with several laborer dealers. The laborer dealers always have a bunch of construction workers at their order. The workers depend on the dealer to find jobs for them. The labor company will sign formal contracts with the dealers about the labor supply and the payment. In the contract, the dealers represent all the workers as a collective. But there are often no formal contracts between the dealers and the workers, as we see in Table 9. At the end of each construction project, or before the Spring Festival, the labor company gets the money from the construction company, that will pay the dealers, and then the dealers distribute the money to hired workers. It could a long period between when the workers start to work and when they get their money. To cover everyday expense, the workers borrow money from the dealers, and the borrowed part will be deducted from total due payment in the final settlement.
} 
Table 12. Average Monthly Income of Migrants and Growth by Regions (based on current and 2008 prices)

\begin{tabular}{|l|c|c|c|c|c|}
\hline & $\mathbf{2 0 0 8}$ & $\mathbf{2 0 0 9}$ & $\mathbf{2 0 1 0}$ & $\mathbf{2 0 1 1}$ & $\mathbf{2 0 1 2}$ \\
\hline $\begin{array}{l}\text { National } \\
\text { Level (yuan) }\end{array}$ & 1340 & 1427 & 1648 & 1895 & 2064 \\
\hline East & 1352 & 1432 & 1653 & 1899 & 2061 \\
\hline Center & 1275 & 1360 & 1591 & 1855 & 2035 \\
\hline West & 1273 & 1388 & 1602 & 1841 & 2007 \\
\hline $\begin{array}{l}\text { Nominal } \\
\text { Growth } \\
\text { (percent): }\end{array}$ & & & & & \\
\hline All & & 5.75 & 19.27 & 21.24 & 11.76 \\
\hline East & & 5.18 & 19.27 & 21.05 & 11.35 \\
\hline Center & & 5.88 & 20.89 & 22.92 & 12.51 \\
\hline West & & 8.25 & 19.23 & 21.12 & 11.86 \\
\hline Source & & & & \\
\hline
\end{tabular}

Source: NBS, China Migrants Monitoring Report 2009-2012

This happened despite the fact that average monthly income of migrants substantially grew also in the eastern region. However growth was somewhat slower than at central and western regions, resulting in the narrowing of the gap. The gap between east and west begun to narrow in 2009, during the implementation of the regional priorities of the stimulus package, when radical increase of western wages may be experienced compared to the previous year.

By 2010 the growth rate of real wages at eastern and central regions tripled while in the west doubled. (In nominal terms, the wage growth rate at eastern and central regions quadrupled, while in the west more than doubled ${ }^{16}$ ). Such radical increase might have been caused regionally by different reasons: in the east, dramatic growth was presumably caused by the developing labor shortage due to the deviation of migration routes to the central and western regions. In the central and western regions, the radical increase might be attributed the labor

\footnotetext{
${ }^{16}$ The real income growth in 2009 was the fastest also by controlled CPI than in the other three years. The major differences between nominal and real income results may be revealed in 2010 and 2011. Using nominal income, growth rate in 2011 is higher than that of 2010, but in real terms it will reverse, referring to the higher inflation of wages in 2011 compared to
} 2010. 
demand caused by the direct impact of the stimulus package. From then on, the growth pace of the eastern and western provinces did not differ spatially, thus the size of income gap between the west and east stabilized. The pace of growth at the center remained the fastest throughout 2012, steadily narrowing the income gap between the eastern and the central regions.

According to Table 13, as a result of growth competition among regions migrants' wages the gap steadily narrowed during the years until almost closing by 2012. By 2012 levelled wage gap ceased to be a relative factor of attraction in the east for migrants.

Table 13 Relative wage level of migrants $($ East $=100)$

\begin{tabular}{|l|c|c|c|c|c|}
\hline & $\mathbf{2 0 0 8}$ & $\mathbf{2 0 0 9}$ & $\mathbf{2 0 1 0}$ & $\mathbf{2 0 1 1}$ & $\mathbf{2 0 1 2}$ \\
\hline East & 100 & 100 & 100 & 100 & 100 \\
\hline Center & 94.30 & 94.97 & 96.25 & 97.68 & 98.74 \\
\hline West & 94.16 & 96.93 & 96.91 & 96.95 & 97.38 \\
\hline
\end{tabular}

Source: NBS, China Migrants Monitoring Report 2009-2011

Not only income conditions but also social security conditions improved though still extremely low in every respect (Table 14). Despite the expanding trend there was a set-back during the 2009 crisis period in pension, accident and medical insurance coverage when the government, responding to the crisis, temporary suspended the implementation of the new labor law. The setback however to be short-lived. From 2010 just as in the case of incomes, security coverage increased steadily, alleviated by the emerging labor demand for migrants in 2010 due to the investments. The highest coverage was experienced in Accident and Medical insurance.

Table 14. Social Security Coverage by type ( percent)

\begin{tabular}{|c|c|c|c|c|c|}
\hline & $\mathbf{2 0 0 8}$ & $\mathbf{2 0 0 9}$ & $\mathbf{2 0 1 0}$ & $\mathbf{2 0 1 1}$ & $\mathbf{2 0 1 2}$ \\
\hline Pension & 9.8 & 7.6 & 9.5 & 13.9 & 14.3 \\
\hline
\end{tabular}




\begin{tabular}{|c|c|c|c|c|c|}
\hline Accident & 24.1 & 21.8 & 24.1 & 23.6 & 24.0 \\
\hline Medical & 13.1 & 12.2 & 14.3 & 16.7 & 16.9 \\
\hline Unemployment & 3.7 & 3.9 & 4.9 & 8.0 & 8.4 \\
\hline Maternity & 2.0 & 2.4 & 2.9 & 5.6 & 6.1 \\
\hline
\end{tabular}

Note: summa number of migrants by security type $=100$. The figures in the table above are the proportion of migrants whose employer provides them with different form of social security. We do not have here the ratio of those paying for themselves, or that of those paying shared with the employer, neither the ratio of those who do not have those types of security at all.

Source: NBS, China Migrants Monitoring Report 2009-2012

The ratio of coverage was and remained much lower in both the center and the west than in the east reflecting the difference in economic and labor market development (Csanádi, Nie, Li, 2013). However, supposedly as a result of increased labor demand owing to recuperating export and improving export structure in the east, versus the attraction of migrants to the central and western regions and government policy, the rapid expansion of social security coverage occurred in all three regions in almost all kinds of securities between 2009 and 2012. Besides growing income and expanding social security, working conditions have improved also regarding working time. We had only national level aggregated figures, and unfortunately, neither regional nor sectoral differences may be uncovered from those. On national level, though the ratio of working months remained stable, and so did working hours per day and the working days within a month, the proportion of migrants working more than 5 days and more than 44 hours a week and more than 8 hours a day is overwhelming, ratios have visibly decreased from 2010 to 2011 (Table 15).

Table 15. Average working time of migrants proportion of migrants by time-length

\begin{tabular}{|l|c|c|}
\hline & $\mathbf{2 0 1 0}$ & $\mathbf{2 0 1 1}$ \\
\hline Months per year & 9.8 & 9.8 \\
\hline Days for Month & 26.2 & 25.4 \\
\hline Hours per day & 9.0 & 8.8 \\
\hline $\begin{array}{l}\text { Proportion of migrants who work } \\
\text { more than 5 days a week }\end{array}$ & 86.4 & 83.5 \\
\hline
\end{tabular}




\begin{tabular}{|l|c|c|}
\hline $\begin{array}{l}\text { Proportion of migrants who work } \\
\text { more than 8 hours a day }\end{array}$ & 49.3 & 42.4 \\
\hline $\begin{array}{l}\text { Proportion of migrants who work } \\
\text { more than 44 hours a week }\end{array}$ & 90.7 & 84.5 \\
\hline
\end{tabular}

Source: NBS, China Migrants Monitoring Report 2009-2011

Concluding the above, regional and sectoral restructuring of migrant flow improved social conditions in several dimensions (wages, social security, working hours). What we cannot predict if this happened due to the one-off impact of the stimulus package that will change when adapting to future favorable or unfavorable economic dynamics or improvements will form a positive tendency for longer term.

\section{Conclusion}

Our results show that the crisis caused a temporary but dramatic set-back in migrant employment while the booming investments incited by the stimulus package increased labor demand well above the pre-crisis period. On the one hand, the temporary set-back in migrant flow had a regional character owing to the coastal concentration of exports hit by the crisis. On the other hand, the stimulus package did restructure migrant routes of the pre-crisis period in accordance with its regional and sectoral priorities. The regional priorities of the stimulus package reinforced the redirection of migrants away from the coast though keeping the east's majority share. Another important new phenomenon was that migrants in all regions increasingly chose to remain in their hukou province rather than migrating out of it. Thus, regional shift in migrant flow has shortened the distance of migration routes and destinations both regionally and within provinces to the detriment of interprovincial migration and destination to the eastern region. The regional shift also incited competition and thereby radical overall wage growth, the closing of the wage gap among regions, the decline of the ratio of migrants with no written work contract, the growth of low social security coverage (mainly accident and medical insurance), and visibly decreased the ratio of migrants working 
lengthy hours a day, a week and a moth.

We have also demonstrated a sectoral impact of the stimulus package on migration. The number of migrants decreased in manufacturing and increased in the prioritized construction. Labor demand and restructuring went parallel to decreasing income disparities among migrants not only regionally but also sectorally.

The migrant flows display several persistent features that may prove to be later temporary as migrants adapt to the dynamics of the impact of the stimulus package or to a new stimulus with different sectoral and regional priorities. Signs of temporary character of so-far tendencies may be also detected: mobilization of the manufacturing sector as a reaction to prioritized input demands is attracting further migrant growth, and so do the reactions of the private sector, the growing labor demand of slowly upward turning export and new investments in the coastal region.

\section{References}

Bukley, Chris. 2009. „China seen facing wave of unrest in 2009”, Reuters http://ca.reuters.com/article/topNews/idCATRE5050F520090106?pageNumber=2\&virtual $\underline{\text { BrandChannel; Tue Jan } 6}$

Cai, Fang and Kam Wing Chan. 2010. The Global Economic Crisis and Unemployment in China http://www.relooney.info/SI_FAO-Asia/China_168.pdf

Cai, Yongshun. 2008. "Conflicts and Modes of Action in China" The China Journal, 59, January, 2008: 89-109;

Cai, Yongshun. 2010. Collective Resistance in China: Why popular protests succeed or fail Stanford: Stanford University Press 
Chan, Kam Wing. 2010. The Global Financial Crisis and Migrant Workers in China: 'There is No Future as a Labourer; Returning to the Village has No Meaning International Journal of Urban and Regional Research, Volume 34.3 September: 659-77

Chan, Kam Wing. 2012. Migration and development in China: trends, geography and current issues http://faculty.washington.edu/kwchan/Chan-migration-China-MD.pdf

"Charter 08"

http://en.wikipedia.org/wiki/Charter_08

Chen, N. 2009. "The present situation and Perspective of Small and Medium Enterprises." Small and Medium Enterprises Review 5: 4-5.

Chiang, Yilin, Emily C. H annum, Grace Kao. 2013. It ' s Not Just About the Money: Motivations for Y outh Migration in Rural China http://repository.upenn.edu/cgi/viewcontent.cgi?article=1005\&context=elmm

China's Slowdown In Coastal Provinces Forces Migrant Workers To Go Home.2012. Forbes, $07-27$

http://article.wn.com/view/2012/07/27/Chinas_Slowdown_In_Coastal_Provinces_Forces_ Migrant_Workers_/

Csanádi, Mária. 2006. Self-Consuming Evolutions: A Model on the Structure, Selfreproduction, Self-destruction and Transformation of Party-states, tested on the Romanian, Hungarian and Chinese Cases Hungarian Academic Press, Budapest

Csanádi, Mária. 2012. "Economic and systemic consequences of adaptation to external and internal pressures caused by global crisis in China” Discussion Papers, MTDP-- 2012/9 http://econ.core.hu/file/download/mtdp/MTDP1209.pdf

Csanádi, Maria (2013) State Intervention, Local Indebtedness, Investment Overheating and Their Systemic Background During Global Crisis in China MTDP 2013/40 
http://econ.core.hu/file/download/mtdp/MTDP1340.pdf

Csanádi, Maria, Nie Ziahn, Li Si .2013. Crisis, Stimulus Package and Migration in China MTDP 2013/41 http://econ.core.hu/file/download/mtdp/MTDP1341.pdf

Demurger, Sylvie. 2012. Mapping modes of rural labour migration in China in Rebalancing and Sustaining Growth in China eds. Huw McKay and Ligang Song, Australian National University, ANU Epress (eds http://epress.anu.edu.au/wpcontent/uploads/2012/06/whole1.pdf

Jennifer Duggan (2013, January 12) Income inequality on the rise in China. Retrieved from http://www.aljazeera.com/indepth/features/2012/12/2012122311167503363.html

Hsu, Sara, Shiyin Jiang, and Halcott Heyward. 2010. The Global Crisis' Impact upon China's Rural Migrants, in: Journal of Current Chinese Affairs, 39, 2: 167-185. http://journals.sub.uni-hamburg.de/giga/jcca/article/view/258/258

Hu, Xiaochu. 2012. China’s “New Generation” Rural-Urban Migrants: Migration Motivation and Migration Patterns http://papers.ssrn.com/sol3/papers.cfm?abstract_id=1978546

Knight, John, DENG Quheng, and LI Shi. 2013. The Evolution of the Migrant Labor Market in China, 2002-2007, in Rising Inequality in China: Challenge to a Harmonious Society LI Shi, Hiroshi Sato, and Terry Sicular, eds. pp. 373-417 Cambridge University Press, Aug 31, 2013, Business and Economics http://books.google.hu/books/about/Rising_Inequality_in_China.html?id=rIesMQEACAAJ $\underline{\text { \&redir_esc }=\mathrm{y}}$

Kong, Sherry Tao, Xin Meng and Dandan Zhang. 2010. Impact of economic slowdown on migrant workers http://epress.anu.edu.au/wp-content/uploads/2011/06/ch124.pdf

Meng, Xin; Kong, Sherry Tao; Zhang, Dandan. 2010. How much do we know about the impact of the economic downturn on the employment of migrants? ADBI working paper series, No. 194, http://hdl.handle.net/10419/53553 
Sicular, Terry, Yue Ximing Björn, Gustafsson and Li Shi .2005. The Urban-Rural Gap and Income Inequality in China http://home.wlu.edu/ smitkam/274/pdfs/sicular percent20urban-rural percent20gap.pdf

Xu, Yingying. 2010. China's Rising Labor Costs and the Labor Shortage Puzzle Issues in Brief, August 17 http://www.mfiintl.com/reports/China_RisingCosts_LaborShortage.pdf

Wong, S.. 2008. "Impacts of the Financial Crisis on Labour Conditions in China". Heidelberg, Werkstatt Ökonomie, 19 December http://www.globalmon.org.hk/en/wpcontent/uploads/2009/02/wong_2008_impacts_of_the_financial_crisis.pdf

Yu, Yongding. 2009. The Impact of the Global Financial Crisis on the Chinese Economy and China's Policy Responses Third World Network, Financial Crisis and Asian Developing Countries, Penang, Malaysia http://www.twnside.org.sg/title2/ge/ge25.pdf 